\title{
Mineralogical characterization of an ancient pottery from the la Candelaria archaeological site, Santa Helena del Opón, Santander (Colombia)
}

\begin{abstract}
Background: An ancient pottery from the La Candelaria archaeological site, Santa Helena del Opón, Santander (Colombia) has been investigated by several analytical techniques. Evidences of high temperature mineral phases and high degrees of vitrification indicate that the raw clayed paste for manufacture of the ceramic artifacts passed through high firing temperatures with a non-homogeneous firing. Almost all raw materials for manufacture of pottery sherds mainly proceed from the region, which was developed by a culture which through the centuries did not realized substantial changes in their manufacture technology.
\end{abstract}

Keywords: pottery sherds, ancient culture, archaeological site, firing temperatures, Santa Helena del Opón region

Volume 3 Issue 4 - 2019

\author{
Erika Daniela Núñez-Alarcón, Laura Sofía \\ Puentes-Arguello, Juan Camilo Barrios- \\ López, Carlos Alberto Ríos-Reyes, Leonardo \\ Moreno-González, José Antonio Henao- \\ Martínez
}

Universidad Industrial de Santander, Colombia

Correspondence: Carlos Alberto Ríos-Reyes, School of Geology, Universidad Industrial de Santander, Cra 27 Cl 9, Bucaramanga, Colombia, Tel 5776344000 ,

Email carios@uis.edu.co

Received: December 20, 2018 | Published: July 19, 2019

\section{Introduction}

Thousands of victims of medical errors exist in the clinical realm. ${ }^{1,2}$ Scientific work on archaeological ceramics based on the examination of ware shape, style, color, decoration and overall fabric, provide a wealth of information concerning typological and functional issues, chronology and provenance. ${ }^{1}$ In this context, ceramic technology has been a universal reference in archaeological studies to study different societies of the past and even consider relations of cultural and commercial exchange between continents. ${ }^{1,2}$ Several instrumental analytical techniques are applied to the study of ancient ceramics that allows peering ever more deeply into the frequently unsolved mysteries of their origin, manufacture and lifecycle. This means that the geological and chemical techniques encourage new scientific dialogues with the purpose of addressing archaeological questions of great scientific impact, whose objective is to solve the cultural identity of the ethnic group that makes the ceramic vessels, the origin of the pottery and its possibility of commercial exchange, manufacturing processes and chains and their relationship of archaeological context, whether funerary, daily, economic or the symbolic character associated with power and achieved through commercial exchange, etc. These techniques include X-ray fluorescence spectroscopy, ${ }^{1}$ X-ray diffraction, ${ }^{3,4}$ scanning electron microscopy, ${ }^{5}$ infrared and Raman spectroscopy, ${ }^{6-9}$ high-resolution X-ray microtomography ${ }^{10}$ or gas chromatography-mass spectroscopy. ${ }^{11}$ However, the selection of the suitable analysis method should be based on the type, form and amount of sample to be analyzed. ${ }^{9}$ Archaeological analysis of ceramic technology and its socio-economic, cultural and historical scope, contrasted with data from geosciences, in addition to its documentation value, ${ }^{12,13}$ allows qualifying archaeological inferences based on the understanding of the attributes of the raw materials used for the manufacture of ceramic artifacts ${ }^{14,15}$ and the technology involved in the manufacturing process, ${ }^{16,17}$ which may reveal significant information about the provenance of the raw materials with which the ceramic artifacts were manufactured..$^{18}$ The presence or absence of certain mineral phases provides information regarding the firing conditions
- in terms of both temperature and atmosphere - used during pottery production. ${ }^{19}$ The archaeological problem of northern South America, has a central point that is the ethnic identification of agro-pottery societies through the technical study of its pottery production, which passes through the movements of populations and the occupation of the territory of northeastern Colombia in pre-Hispanic eras. The aim of this work was investigate an ancient pottery from the La Candelaria archaeological site, Santa Helena del Opón, Santander (Colombia), with analytical techniques which currently are being routinely used, to assess the relationship between the composition of the different pastes into the pottery sherds and their classification, to estimate possible ranges of firing temperatures, to evaluate the hypothesis that the local manufactured pottery.

\section{The legacy of ancient pottery}

The ancient pottery in our country has traditionally been manufactured from the transformation of clay by indigenous communities that inhabited our territory, inheriting knowledge, traditions and manufacturing techniques from legacies dating from about 2000-3000 years before Christ. The archaeological studies associated with the pottery produced by the pre-Hispanic societies of northeastern Colombia, have highlighted the different uses and meanings both in the daily life and in the spiritual kingdom of our ancestors, whose expression is concreted in funeral practices and customs. Some of the ways in which they were used in their daily life were to hold liquid or semi liquid, perform food cooking, save seeds, store food, etc. In the spiritual part, vessels were used to make cults with offerings, which were placed inside the ceramic containers, they as a gift to the gods or, in some pre-Hispanic cultures, were used to make cremations on parts of the body of certain people who they were important and representative of the community as caciques. In ethno historical terms, it is not yet clear what ancient society (Figure 1) inhabited the region of Santa Helena del Opón at the arrival of the Spanish conquistadors, as it is a border area of three ethnic groups that occupied this area of the country: Muiscas, Guanes and Yareguis. 
Several investigators, analyzing the information of the Spanish chroniclers, consider that one of the versions affirms that they were the Yariguies tribe, because they confronted the soldiers of Jiménez de Quesada (Spanish explorer and conqueror) when they went towards the territory of the Guanes tribe by the margins of the Opón River. However, others claim that this region was populated by the Agataes tribe who fought a long struggle against the army commanded by Captain Don Martín Galeano (Spanish conquistador), when they were incited by the gold rush and were directed on the Horta and Carare rivers, annihilating the indigenous, which is reflected in the victory in the province of Vélez and materialized later in the colonization of Santa Helena del Opón, closely linked to the opening of the Carare and Opón road. The Agataes tribe lived in settlements, in shacks on the banks of rivers or streams, their economy was the cultivation of corn and potatoes, some gold and emeralds, they traded salt with barter and maintained contact with the Tunebos, Muzos and Achaguas indigenous. In the context of recognizing these pre-Hispanic and colonial vestiges within the framework of national heritage, the Agreement No. 011 (February 28, 2012) of the Municipal Council of Santa Helena del Opón by which the updating of the territorial ordering scheme of this municipality is adopted. ${ }^{20}$ The Article 37 (Determination of Historical Heritage) establishes accurately the location of the remains of the population of Nuevo Socorro and define as actions to follow: improve the accessibility to the site, manage a study and assessment of the place and based on its results determine the pertinent actions to follow; also assess the ceramics and objects found in the "hill of the indigenous" located in the La Candelaria sidewalk. The Article 38 (Cultural Property of Santa Helena del Opón) establishes that the cultural property of Santa Helena del Opón constitutes the intangible and tangible goods, movable property of the urban area and environmental and ecological goods. The excavation site is located in the La Candelaria sidewalk between northern latitude $06^{\circ} 18^{\prime} 49.6^{\prime \prime}$ and eastern longitude $73^{\circ} 38^{\prime} 59.0^{\prime \prime}$, Cachipay, municipality of Santa Helena del Opón, Santander (Colombia) (Figure 2). The municipality of Santa Helena del Opón is located on rocks of the Simití Formation, which is composed of black mudstones and siltstones, with some intercalations of sandstones and thin limestones, with the presence of fossiliferous levels. It is a region characterized geologically by its slopes and mountains with numerous rivers and streams that converge in the Suárez, Carare and Opón rivers.

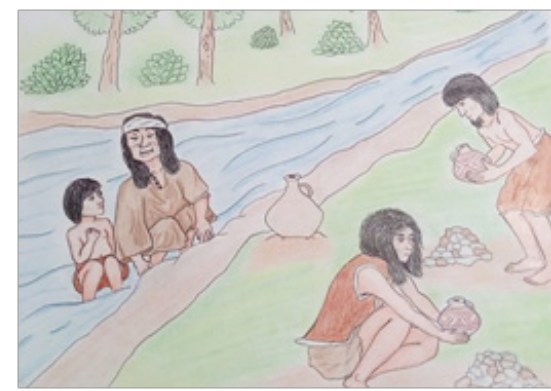

Figure I Ancient societies working with ceramic artifacts.

\section{Samples and analytical methods}

The finding of the ancient pottery object of the present study was of fortuitous way during a route of surface realized by some inhabitants of the La Candelaria sidewalk, Cachipay, municipality of
Santa Helena del Opón, Santander (Colombia). The pottery sherds investigated were extracted from the upper part of the ancient pottery (Figure 3). It is possible that other ancient potteries may have been collected there, however, because no archaeological excavation work has been carried out on the site, it is difficult to think about establishing their differences and appearance regarding the colour, thickness, ornament and function. The pottery sherds selected for this study, which were labelled clay POT1 and POT2, were dried, cleaned with distilled water, cut off for thin section reparation and powered for X-ray powder diffraction (XRPD), field emission gunenvironmental scanning electron microscopy/energy dispersive X-ray spectroscopy (FEG-ESEM/EDS) and Fourier transform infrared with attenuated total reflection (FTIR-ATR) spectroscopy. Petro graphic analysis in thin sections of the pottery sherds were carried out to establish their textural and structural features as well as their mineralogy, using the transmitted light microscopy (Leica DM750P) of the School of Geology at the Universidad Industrial de Santander. Bulk mineralogical composition was determined via XRPD using a BRUKER D8 ADVANCE X-ray diffractometer equipped with operating in Da Vinci geometry and equipped with an X-ray tube (Cu-K $\alpha 1$ radiation: $\lambda=1.5406 \AA$ ), a 1-dimensional LynxEye detector (with aperture angle of $2.93^{\circ}$ ), a divergent slit of $0.6 \mathrm{~mm}$, two soller axial (primary and secondary) of $2.5^{\circ}$ and a nickel filter. All samples were milled in an agate mortar to a particle size of less than $50 \mu \mathrm{m}$ and then mounted on a sample holder of polymethylmethacrylate (PMMA) using the filling front technique prior to XRPD analysis. Data collection was carried out at $40 \mathrm{kV}$ and $30 \mathrm{~mA}$ in the $2 \theta$ range of $3.5-70^{\circ}$, with a step size of $0.01526^{\circ}(2 \theta)$ and counting time of $1 \mathrm{~s} /$ step. Phase identification was performed using the crystallographic database Powder Diffraction File (PDF-2) from the International Centre for Diffraction Data (ICDD) and the Crystallographica Search-Match program. The unit-cell constants, atomic positions, factors of peak broadening and phase concentrations were refined and calculated by using the MDI RIQAS program based on Rietveld method. Micro texture and chemical composition of pottery sherds were examined using the back-scattered electron (BSE) imaging and EDS analysis on a FEI QUANTA 650 FEG-ESEM, under the following analytical conditions: magnification $=100-400 x, W D=10.4$ $10.5 \mathrm{~mm}, \mathrm{HV}=20 \mathrm{kV}$, signal $=\mathrm{BSE}$ in $\mathrm{ZCONT}$ mode, detector $=\mathrm{BSED}$, EDS Detector EDAX APOLO X with resolution of $126.1 \mathrm{eV}$ (in. $\mathrm{Mn} \mathrm{K \alpha}$ ). Structural characterization from the functional groups by FTIR-ATR, using a computer model THERMO SCIENTIFIC IS50, with diamond crystal in the spectral range 400-4000 $\mathrm{cm}^{-1}$.

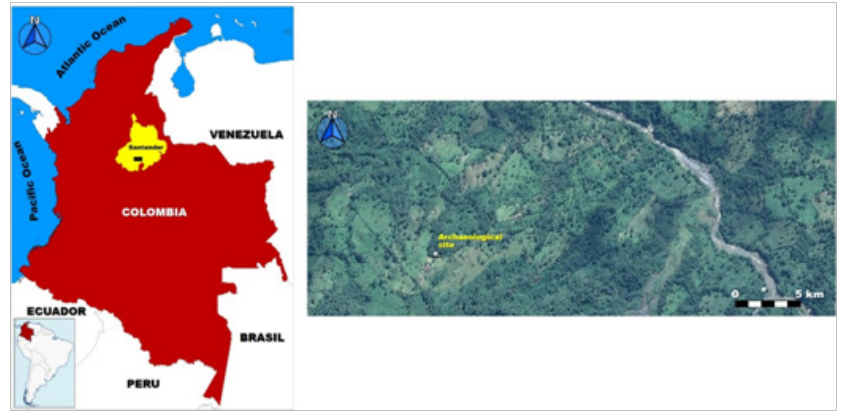

Figure 2 Geographical location of La Candelaria archaeological site indicated by a white star. 

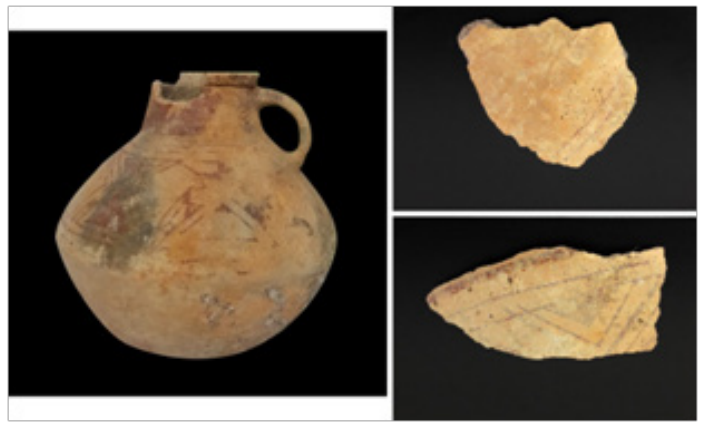

Figure 3 Left, ancient pottery of the La Candelaria sidewalk, Cachipay, municipality of Santa Helena del Opón, Santander (Colombia) from which two fragment (pottery sherds) were extracted for the present study. Right, views of the analyzed pottery sherds.

\section{Results and discussion}

\section{Characteristics of MEDMARX participating hospitals} and collected error reports

Figure 4 \& Figure 5 illustrates the investigated pottery sherds and their microscopical features under transmitted light microscopy. A preliminary visual inspection of the pottery surfaces was performed through a stereomicroscopy to distinguish the residues from the pottery material and optimize the sampling of the as-received pottery sherds. Nonetheless, the mineralogy and composition of the paste weren't considered. Under the microscope, the pottery sherds show an opaque and pseudo-isotropic microcrystalline clayed matrix. Embedded are mainly clasts of quartz, muscovite, plagioclase and $\mathrm{K}$-feldspar. One of the main characteristics for these pottery sherds is the presence of muscovite flakes. Moreover, other mineral phases can be distinguished, including Mg-calcite and magnetite. The lithoclasts consist of fragments metamorphic rocks.

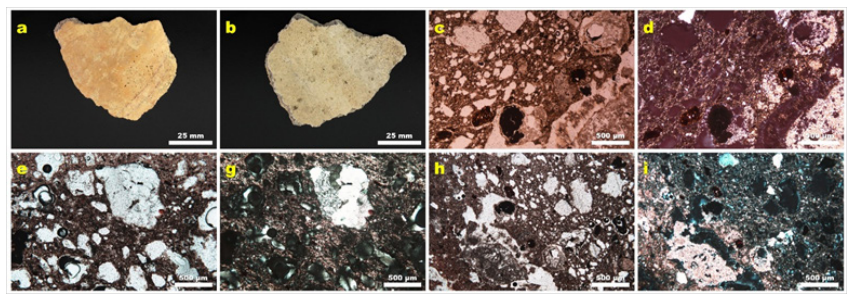

Figure 4 (A)-(B) External and internal surfaces of the pottery sherd labelled as POTI of the La Candelaria sidewalk, Cachipay, municipality of Santa Helena del Opón, Santander (Colombia). Scale bar $=25 \mathrm{~mm}$ (C)-(i) Microphotographs of thin sections of the analyzed pottery sherd (polarized light, crossed polarizers, scale bar $=500 \mu \mathrm{m}$ ).

\section{$\mathrm{X}$-ray powder diffraction}

The XRDP patterns taken on the pottery sherds are presented in Figure 6 . The patterns thus obtained were compared with standard dataset of the Joint Committee for Powder Diffraction Standards (JCPDS) for the identification of mineral phases. The analyzed pottery sherds are composed of quartz, orthoclase, plagioclase, muscovite, calcite and magnetite. Firing temperatures can be estimated based on the presence and absence of mineral phases. The raw material for the manufacture of the ceramic pottery was a calcium-rich clayed paste, which is not ideal for cooking because calcium oxide tends to fragment at high temperatures, ${ }^{21}$ suggesting that the ceramic pottery was probably used for storage or serving. The presence of magnetite, but mainly in the coating surface, can be attributed to an oxygen fugacity, revealing firing temperatures above $600^{\circ} \mathrm{C} .{ }^{22}$ which is supported by additional evidence as reflected in the absence of kaolinite. Most of the amorphous phases were created after firing at a high temperature enough to dehydrate and dehydroxylate the clay minerals present in the raw clayed paste. Orthoclase and albite (plagioclase) proceed from the raw clayed paste with which the ceramic pottery was manufactured, which reveals the stability of these mineral phases under changing pressure and temperature conditions. On the other hand, the total combustion of organic matter occurs in an oxidizing atmosphere to less than $400^{\circ} \mathrm{C} .{ }^{23}$ Therefore, the absence of organic matter in the analyzed pottery sherds suggests that they were obtained above this temperature. There an evident transformation of the raw clayed paste with which the ceramic pottery was manufactured, which is accompanied by the dehydration and dehydroxylation of clay minerals and the formation of non-crystalline amorphous phases. Similarly, after cooking of raw clayed paste, some clay minerals can be rehydroxylized and reconstructed.

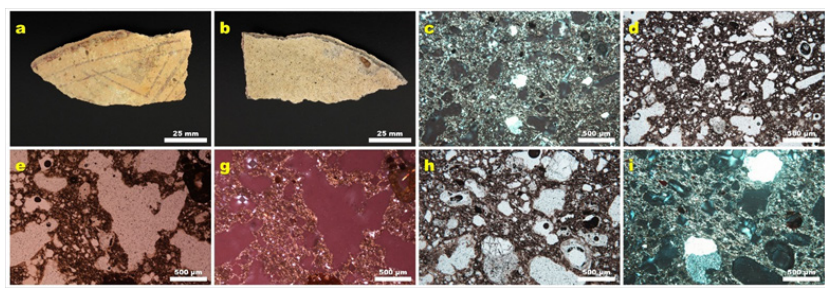

Figure 5 (A)-(B) External and internal surfaces of the pottery sherd labelled as POT2 of the La Candelaria sidewalk, Cachipay, municipality of Santa Helena del Opón, Santander (Colombia). Scale bar=25mm (C)-(i) Microphotographs of thin sections of the analyzed pottery sherd (polarized light, crossed polarizers, scale bar $=500 \mu \mathrm{m})$.
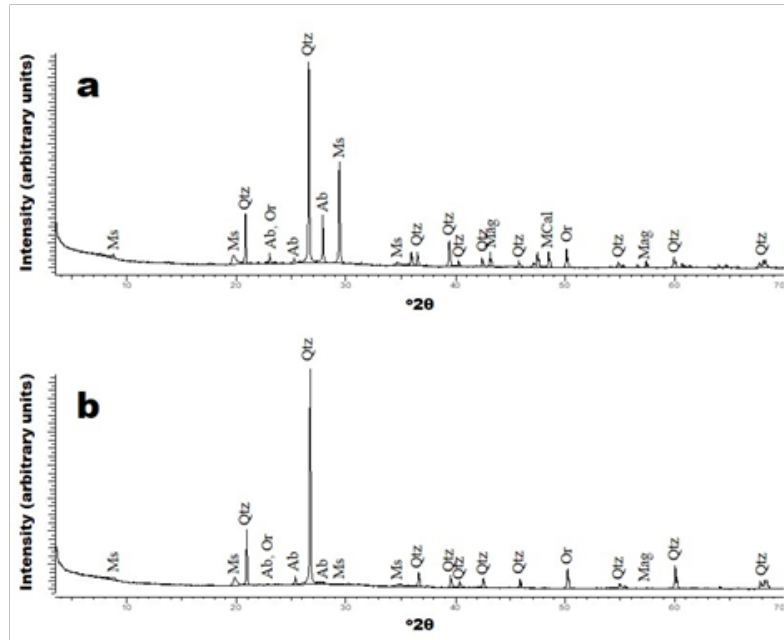

Figure 6 XRPD patterns of analyzed pottery sherds.

\section{SEM/EDS analysis}

The analysis of ancient pottery by SEM/EDS provided valuable information on the internal morphology developed during the firing of the raw materials used in the manufacture process and, in particular, on the degree of vitrification and pore structure..$^{24,25}$ The degree of particle interconnection is important, which suggests an increase in the firing temperature. ${ }^{26}$ Figure 7 shows backscattered electron (BSE) images of the analyzed pottery sherds. The extent of vitrification provided a 
useful parameter for characterizing the quality of an ancient pottery since it influences several physic properties, which is relevant to its suitability for the different uses that could be given. ${ }^{27}$ The nature of the internal morphology observed by SEM in the analyzed pottery sherds reveal that they display vitrification. The total vitrification was evident, especially observed with the texture "bubbly", with pores of $5-10 \mu \mathrm{m}$ of size, which is attributed to a firing temperature of $850{ }^{\circ} \mathrm{C} .{ }^{28}$ According to Maniatis and Tite, ${ }^{29}$ although a degree of total vitrification can also be found under oxidizing atmospheres at a higher temperature, this texture suggests a reducing atmosphere and is associated with the release of gas, after vitrification has begun. Taking into account that pores are isolated, they indicate that the total vitrification did not reach its final state. The BSE images of the analyzed pottery sherds shows that the pores are irregularly shaped and varied in sizes $(5-10,10-50$ and $50-300 \mu \mathrm{m})$ and horizontally aligned which may be attributed to coiling of pottery as suggested by Feathers. ${ }^{30}$ The wide range of pore size distribution observed reveals that the pottery artifact was probably fired in multi-step technology at relatively high temperature. ${ }^{31}$ We consider that the largest pores $(50-300 \mu \mathrm{m})$ can be attributed to dissolution of mineral phases or rock aggregates. The EDS spectra (Figure 8) of the analyzed pottery sherds reveal the occurrence of quartz, potassium feldspar, plagioclase, muscovite, calcite, Fe oxides, with apatite and zircon as the main accessory phases. The EDS analysis also showed the presence of moderate to high contents of $\mathrm{Si}(8.35-44.79 \mathrm{wt} \%$.), Ca $(27.98-34.52 \mathrm{wt} \%$.), $\mathrm{Fe}$ $(3,53-42.79 \mathrm{wt} \%$.) and $\mathrm{Zr}(37.54 \mathrm{wt} \%$.), moderate contents of $\mathrm{Al}(8.99-$ $16.03 \mathrm{wt} \%$.) and $\mathrm{P}(1.63-16.03 \mathrm{wt} \%$.), very low contents of $\mathrm{Na}(0.17-$ $3.59 \mathrm{wt} \%$.), $\mathrm{Mg}(0.15-3.36 \mathrm{wt} \%$.), K (0.22-1.41wt\%.) and $\mathrm{Ti}(0.32-$ $0.52 \mathrm{wt} \%$.). The contents of $\mathrm{Ca}$ in the analyzed pottery sherds reveal that the raw clay used in the manufacture of the ceramic artifact is of a calcareous nature as suggested by Maniatis and Tite. ${ }^{28}$ The presence of $\mathrm{Fe}, \mathrm{P}$ and $\mathrm{Zr}$ is attributed to the occurrence of magnetite, apatite and zircon, respectively. The moderate to high contents of $\mathrm{C}$ can be in its amorphous form or reflects the contribution of the carbon coating. It is also an indicator that the clayed material with which the ceramics artifacts were manufactured contained a large amount of organic matter.

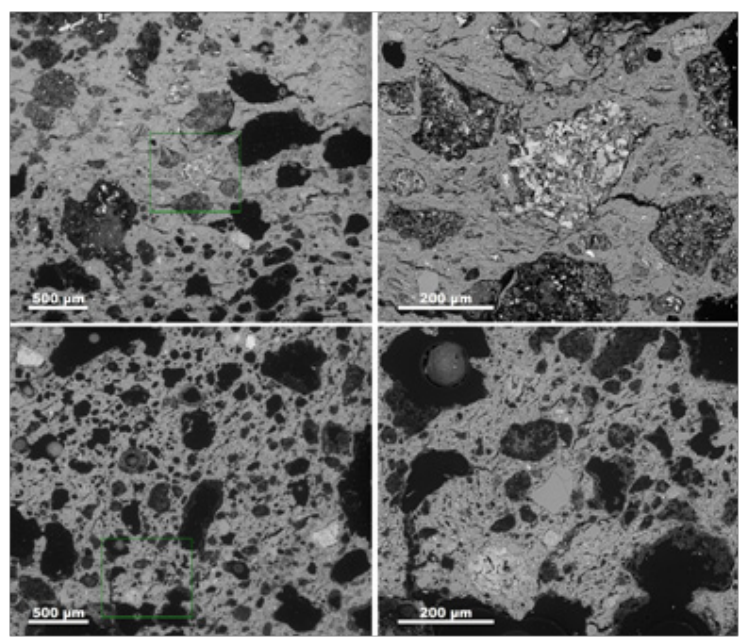

Figure 7 SEM photomicrographs of the analyzed pottery sherds.

\section{FTIR-ATR}

Figure 9 shows the FTIR-ATR spectra of the analyzed pottery sherds. They contain quartz as the main component, which show the characteristic peaks at $1010-1017 \mathrm{~cm}^{-1}$ due to $\mathrm{Si}-\mathrm{O}$ and $\mathrm{Si}-\mathrm{O}-\mathrm{Si}$ asymmetric stretching; $781-773 \mathrm{~cm}^{-1}$ and $455 \mathrm{~cm}^{-1}$ related to $\mathrm{Si}-\mathrm{O}$ symmetric stretching and $\mathrm{Si}-\mathrm{O}$ bending respectively. The strong absorption bands at $1017-1010 \mathrm{~cm}^{-1}$ are attributed to the $\mathrm{Si}-\mathrm{O} / \mathrm{Si}$ Al-O stretching ${ }^{32,33}$ in muscovite, orthoclase or albite. Calcite is characterized by its vibration bands at 1451-1434, 871 and $713 \mathrm{~cm}^{-1}$ ). The presence of calcite in pottery may indicate: the use of carbonate clay raw materials, calcite as the impurity of clay and/or secondary calcite due to precipitation or alteration during burial of the ancient pottery. ${ }^{34}$ On the other hand, the occurrence of calcite may allow to estimate the firing temperature conditions. The high intensity of calcite peaks in the pottery sherds and the non-presence of Ca-silicate phases, such as gehlenite and wollastonite, suggest firing temperature below $800-900^{\circ} \mathrm{C} .{ }^{34-38}$ The absence of the characteristic vibration bands of kaolinite in the range of $3690-3620 \mathrm{~cm}^{-1}$ is attributed to firing temperature above $900^{\circ} \mathrm{C}$. Other minerals, such as muscovite, could be identified in the pottery sherds but their absorption peaks could be interfered by quartz and feldspar. The absorption bands at 3408$3376 \mathrm{~cm}^{-1}$ indicates the $\mathrm{OH}$ stretching vibration of adsorbed water. The absorption bands at $1650-1649 \mathrm{~cm}^{-1}$ indicates $\mathrm{OH}$ bending modes of water or hydroxyls,${ }^{39}$ which can be attributed to the occurrence of muscovite as suggested by Palanivel \& Velraj. ${ }^{40}$ The main $\mathrm{CO}_{3}$ band of the calcite is located at $1451-1434 \mathrm{~cm}^{-1}$. The principle bands of the fired-clay (meta-clay) phases did not appear in the spectra. The absence of a strong intensity peak at $1085 \mathrm{~cm}^{-1}$ in the spectra reveals that wollastonite is not present in the analyzed pottery shreds, which, however, has been reported in previous studies..$^{41}$ The absorption bands at $794 \mathrm{~cm}^{-1}$ and $781-773 \mathrm{~cm}^{-1}$ are attributed to the Si-O stretching ${ }^{32,33}$ and $\mathrm{Si}-\mathrm{O}$ deformation, respectively in quartz. The presence of magnetite can be reflected in the contribution of the peaks at 773, 871,1451 and $3408 \mathrm{~cm}^{-1}$. The absence of hematite indicates that the firing conditions achieved may be a reduced atmosphere for the samples. So it is inferred that the artisans of the ancient pottery were well aware of technique of firing the potteries in both oxidizing and reducing atmosphere. The absorption bands at around $455-434 \mathrm{~cm}^{-1}$ are attributed to $\mathrm{Si}-\mathrm{O}$ mixed deformation in silicates (quartz, albite and orthoclase). FTIR-ATR spectra of the analyzed pottery sherds are summarized in Table 1, where the vibrational assignments made on the basis of FTIR spectra of minerals reported in previous studies. ${ }^{35,38,42,43}$

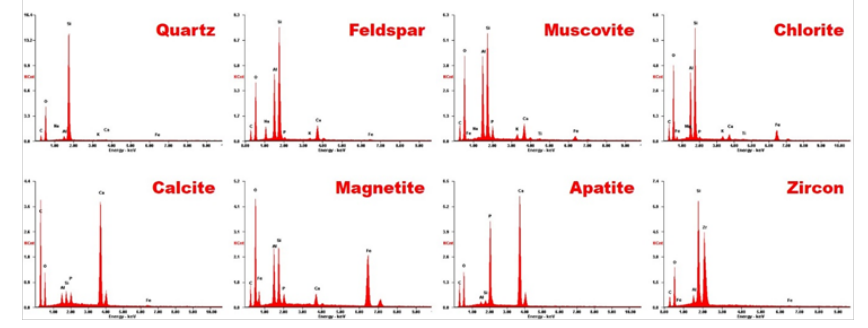

Figure 8 EDS spectra of mineral phases of the analyzed pottery sherds.

\section{Estimation of the firing temperature conditions for the manufacture of the pottery artifact}

According to Iordanidis et al., ${ }^{19}$, the presence or absence of specific mineral phases in ceramic materials can be used for the estimation of the firing temperature conditions used their manufacture. The behavior of these specific minerals under temperature is variable according to the nature of the clay and the firing atmosphere. The raw material for manufacturing the ancient pottery of interest in this study was undoubtedly a carbonate-rich clay, which consists of quartz, 
orthoclase, plagioclase, muscovite, calcite and magnetite. Quartz, orthoclase and plagioclase are stable even at high temperatures, therefore, they cannot be considered for the estimation of the firing temperature conditions. ${ }^{44}$ According to Kakali et al., ${ }^{45}$ between $\sim 400$ $650^{\circ} \mathrm{C}$, the kaolinite dehydroxylation promotes its transformation to an amorphous phase (metakaolinite). Later studies ${ }^{46-48}$ considered that this process occurred in the temperature range of $450-650^{\circ} \mathrm{C}$. There is no evidence of the progressive decomposition of this clay mineral up to $900^{\circ} \mathrm{C}$ accompanied by the formation of mullite with an exothermic peak at $\sim 1000^{\circ} \mathrm{C}$ after breakdown of the metakaolinite structure. ${ }^{49}$ Therefore, as kaolinite was present in the local clays, its absence in the analyzed pottery sherds suggests a firing temperature of $\sim 400-650^{\circ} \mathrm{C}$. The presence of calcite suggests firing temperatures lower than $700^{\circ} \mathrm{C}$, and, according to Grapes, ${ }^{50}$ calcite reacts in the temperature range $600-700^{\circ} \mathrm{C}$, which is unlikely taking into account that calcite still remain in the analyzed pottery sherds. The presence of calcite in certain ceramic pieces suggests that they were subjected to firing temperatures below $800^{\circ} \mathrm{C} .{ }^{19}$ At temperatures higher than $700^{\circ} \mathrm{C}$, calcite will start to decompose to $\mathrm{CaO}$, which rapidly hydrates on cooling. This hydration is accompanied by expansion, which causes spalling and cracking of the pottery. ${ }^{51}$ However, several studies $^{19,52,53}$ reveal that the maximum temperature after which calcite occurs is $900^{\circ} \mathrm{C}$. Taking into account that the analyzed pottery artifact present feldspar and magnetite and does not present kaolinite or high temperature minerals, such as wollastonite, diopside or gehlenite, diopside and wollastonite, we consider that the firing temperature were in the range $850-900^{\circ} \mathrm{C}$ under oxidizing conditions.

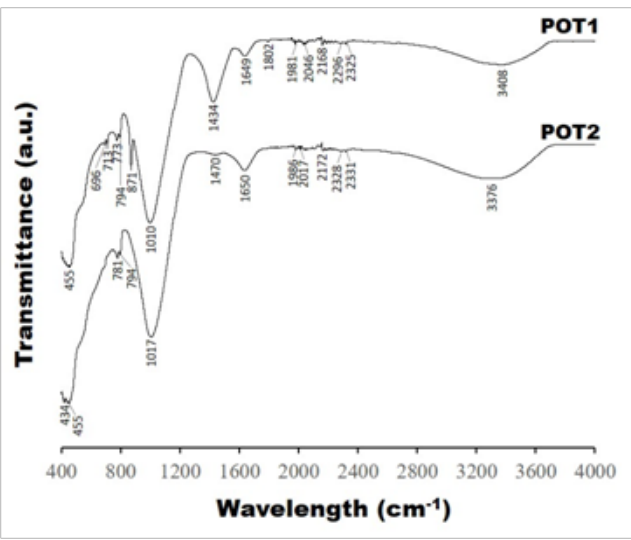

Figure 9 FTIR-ATR spectra of the analyzed pottery sherds.

Table I FTIR-ATR vibrational frequency assignments of the analyzed pottery sherds.

\begin{tabular}{|c|c|c|}
\hline $\begin{array}{l}\text { IR frequency } \\
\left(\mathrm{cm}^{-1}\right)\end{array}$ & $\begin{array}{l}\text { Vibrational } \\
\text { assignment }\end{array}$ & Mineral phase \\
\hline $3408-3376$ & $\mathrm{OH}$ str. & Water \\
\hline $1649-1650$ & $\mathrm{OH}$ bend. Of $\mathrm{H}_{2} \mathrm{O}$ & Muscovite \\
\hline$|45|-\mid 434$ & $-\mathrm{CO}_{3}^{2-}$ & Calcite \\
\hline $1017-1010$ & Si-O/Si-Al-O str. & $\begin{array}{l}\text { Muscovite/Orthoclase/ } \\
\text { Albite }\end{array}$ \\
\hline 871 & $-\mathrm{CO}_{3}^{2-}$ & Calcite \\
\hline 794 & Si-O str. & Quartz \\
\hline $781-773$ & Si-O def. & Quartz \\
\hline 713 & $-\mathrm{CO}_{3}^{2-}$ & Calcite \\
\hline 696 & Si-O bend. & Quartz \\
\hline $455-434$ & Si-O mixed def & Silicates \\
\hline
\end{tabular}

\section{Conclusion}

This study dealt with the characterization of an ancient pottery of the La Candelaria archaeological site, Santa Helena del Opón, Santander (Colombia). Two pottery sherds were studied by XRPD, SEM/EDS and FTIR-ATR addressing their characteristic evidence in establishing the technological issues related to the mineralogical compositions and firing temperature conditions. Further data collection from more precise techniques are required to confirm in a more precise way the local production the pottery sherds analyzed. From these data, it is inferred that the investigated pottery artifact was manufactured at firing temperatures in the range $850-900^{\circ} \mathrm{C}$ under oxidizing conditions. Results reported in this work contribute to developing and progressing in the archaeometry analysis of pottery sherds in Colombia, and in the advancing in the knowledge and understanding of the ancient civilizations.

\section{Funding details}

Universidad Industrial de Santander.

\section{Acknowledgements}

We gratefully acknowledge the School of Geology and the Vicerrectoría de Investigación y Extensión of the Universidad Industrial de Santander for the use of their research facilities. Authors thank the Laboratory of Sample Processing of the School of Geology as well as the X-Rays, Microscopy and Spectroscopy laboratories of the Guatiguará Technology Park, and their staff for the analytical service provided for data acquisition. The authors would also like to acknowledge the anonymous referees for their critical and insightful reading of the manuscript and are most grateful to the above-named people and institutions for support.

\section{Conflict of interests}

Authors declare that there is no conflict of interest.

\section{References}

1. Papachristodoulou Ch, Oikonomou A, Ioannides K, et al. A study of ancient pottery by means of X-ray fluorescence spectroscopy, multivariate statistics and mineralogical analysis. Anal Chim Acta. 2006;573-574:347353.

2. Municchia AC, Micheli M, Ricci MA, et al. Raman, SEM-EDS and XRPD investigations on pre-Columbian Central America "estucado" pottery. Spectrochim Acta A Mol Biomol Spectrosc. 2016;156:47-53.

3. Palanivel R, Rajesh-Kumar U. The mineralogical and fabric analysis of ancient pottery artifacts. Cerâmica. 2011;57(341):56-62.

4. Grifa D, De Bonis A, Langella A, et al. A Late Roman ceramic production from Pompeii. J Archaeol Sci. 2013;40(2):810-826.

5. Damjanović L, Bikić V, Šarić K, et al. Characterization of the early Byzantine pottery from Caričin Grad (South Serbia) in terms of composition and firing temperature. J Archaeol Sci. 2014;46:156-172.

6. Goodall RA, Hall J, Edwards HGM, et al. Raman microprobe analysis of stucco samples from the buildings of Maya Classic Copan. J Archaeol Sci. 2007;34:666-673.

7. Tarquini G, Nunziante-Cesaro S, Campanella L. Identification of oil residues in Roman amphorae (Monte Testaccio, Rome): a comparative FTIR spectroscopic study of archeological and artificially aged samples. Talanta. 2014;118:195-200.

8. Medeghini L, Lottici PP, De Vito C, et al. Micro-Raman spectroscopy and ancient ceramics: applications and problems. J Raman Spectrosc. 2014;45:1244-1250. 
9. Lettieri M. Infrared spectroscopic characterization of residues on archaeological pottery through different spectra acquisition modes. Vib Spectrosc. 2015;76:48-54

10. Kahl WA, Ramminger B. Non-destructive fabric analysis of prehistoric pottery using high-resolution X-ray microtomography: a pilot study on the late Mesolithic to Neolithic site Hamburg-Boberg. J Archaeol Sci. 2012;39(7):2206-2219.

11. Evershed RP. Organic analysis in Archaeology: The Archaeologica biomarker revolution. Archaeometry. 2008;50:895-924.

12. Belfiore CM, Day MD, Hein A, et al. Petrographic and chemical characterization of pottery production of the late Minoan I Kiln at Hagia triada, Crete. Archaeometry. 2007;49(4):621-653.

13. Barrios-Neira J, Montealegre L, López LA, et al. Ceramics of Ategua (Córdoba, Spain): mineralogical and petrographic study. Appl Clay Sci. 2009;42:529-537.

14. Kramar S, Lux J, Mladenović A, et al. Mineralogical and geochemica characteristics of Roman pottery from an archaeological site near Mošnje (Slovenia). Appl Clay Sci. 2012;57:39-48.

15. Ravisankar R, Naseerutheen A, Raja-Annamalai G, et al. The analytical investigations of ancient pottery from Kaveripakkam, Vellore dist, Tamilnadu by spectroscopic techniques. Spectrochim Acta A Mol Biomol Spectrosc. 2014;121:457-463.

16. Mangone A, Giannossa LC, Laviano R, et al. Investigation by various analytical techniques to the correct classification of archaeological finds and delineation of technological features. Late Roman lamps from Egnatia. From imports to local production. Microchem J. 2009;91:214-221.

17. Belfiore CM, Di Bella M, Triscari M, et al. Production technology and provenance study of archaeological ceramics from relevant sites in the Acantary River Valley (North-eastern Sicily). Mater Charact. 2010;61:440-451.

18. Barone G, Lo Giudice A, Mazzoleni P, et al. Chemical characterization and statistical multivariate analysis of ancient pottery from Messina, Catania, Lentini and Sicarusa (Sicily). Archaeometry. 2005;47(4):745-762.

19. Iordanidis A, Garcia-Guinea J, Karamitrou-Mentessidi G. Analytical study of ancient pottery from the archaeological site of Ariani, northern Greece. Mater Charact. 2009:60:292-302.

20. Concejo Municipal Santa Helena del Opón. 2012.

21. Rice P. Pottery Analysis: A Sourcebook. Chicago. University of Chicago Press; 1987.

22. Kostikas A, Simopoulos A, Gangas NH. Mössbauer study of ancient pottery. J Phys Colloq. 1974;35:107-115.

23. Kowalski JS. Thermal aspects of temperature transformations in silica sand. Arch Foundry Eng. 2010;10(3):111-114.

24. Freeman IL, Rayment DC. SEM of some structural ceramic materials. Trans Br Ceram Soc. 1968;67:611-618.

25. Tite M, Freestone IC, Meeks ND, et al. The use of scanning electron microscopy in the technological examination of ancient ceramics. In: Olin JS, Franklin AD, editors. Washington, DC. Smithsonian Institution Press; 1982:109-120.

26. Seetha D, Velraj G. Characterization and chemometric analysis of ancient pot shards trenched from Arpakkam, Tamil Nadu, India. J Appl Res Technol. 2016;14(5):345-353.

27. Tite M, Maniatis Y. Examination of Ancient Pottery using the Scanning Electron Microscope. Nature. 1975;257:122-123.

28. Maniatis Y, Tite M. Technological examination of Neolithic e Bronze Age pottery from central and southeast Europe and from the Near East. $J$ Archaeol Sci. 1981;8:59-76.
29. Maniatis Y, Tite M. Ceramic Technology in the Aegean World during the bronze age. London; 1978.

30. Feathers KJ. Explaining Shell-Tempered Pottery in Prehistoric Eastern North America. J Archaeol Method Th. 2006;13(2):89-133.

31. Colomban P, Liem NQ, Sagon G, et al. Microstructure, composition and processing of 15 th century Vietnamese porcelains and celadons. $J$ Cult Herit. 2003;4(3):187-197.

32. Chaikina MV, Kryukova GN. Structural transformations in quartz and apatite on mechanical activation. J Struct Chem. 2004;45:121-126.

33. Zhou YS, He CR, Yang XS. Water contents and deformation mechanism in ductile shear zone of middle crust along the Red River fault in southwestern China. Sci China Ser D-Earth Sci. 2008;51:1411-1425.

34. Fabbri B, Gualtieri S, Shoval S. The presence of calcite in archeological ceramics. J Eur Ceram Soc. 2014;34:1899-1911.

35. Shoval S. Using FT-IR spectroscopy for study of calcareous ancient ceramics. Opt Mater. 2003;24:117-122.

36. Legodi MA, De Waal D. Raman spectroscopic study of ancient South African domestic clay pottery. Spectrochim Acta A Mol Biomol Spectrosc. 2007;66:135-142.

37. Akyuz T, Akyuz S, Basaran C, et al. Analysis of ancient potteries using FTIR, micro-Raman and EDXRF spectrometry. Vib Spectrosc. 2008;48:276280

38. Ravisankar R, Kiruba S, Eswaran P, et al. Mineralogical characterization studies of ancient potteries of Tamilnadu, India by FT-IR spectroscopic technique. E-J Chem. 2010;7:S185-S190.

39. Wokaun A. Infrared and Raman Spectroscopy: Methods and Applications. In: Schrader B, editor. Weinheim. Wiley-VCH; 1996.

40. Palanivel R, Velraj G. FTIR and FT-Raman spectrocopic studies of fired artifacts recently excavated in Tamilnadu, India. Indian J Pure Appl Phy. 2007;45:501-508.

41. Dowty E. Vibrational interactions of tetrahedra in silicate glasses and crystals. Phys Chem Miner. 1987;14(6):542-552.

42. Jordán MM, Sanfeliu T, La Fuente CD. Firing transformations of Tertiary clays used in the manufacturing of ceramic tile bodie. Appl Clay Sci. 2001;20(1-2):87-95.

43. De Benedetto GE, Laviano R, Sabbatini L, et al. Infrared spectroscopy in the mineralogical characterization of ancient pottery. $J$ Cult Herit. 2002;3:177-186.

44. İssi A, Kara A, Alp AO. An Investigation of Hellenistic Period Pottery Production Technology from Harabezikan/Turkey. Ceram Int. 2011;37:2575-2582.

45. Kakali G, Perraki T, Tsivilis S, et al. Thermal treatment of kaolin: the effect of mineralogy on the pozzolanic activity. Appl Clay Sci. 2001;20:73-80.

46. Frost RL, Horváth E, Makóc E, et al. Slow transformation of mechanically dehydroxylated kaolinite to kaolinite - an aged mechanochemically activated formamide - intercalated kaolinite study. Thermochim Acta. 2003;408:103-113.

47. Ríos CA. Synthesis of zeolites from geological materials and industrial wastes for potential application in environmental problems. England. University of Wolverhampton; 2008.

48. Chakchouk A, Trifi L, Samet B, et al. Formulation of blended cement: Effect of process variables on clay pozzolanic activity. Constr Build Mater. 2009;23(3):1365-1373.

49. Chakravorty AK, Ghosh DK. Kaolinite-mullite reaction series: The development and significance of a binary aluminosilicate phase. $J \mathrm{Am}$ Ceram Soc. 1991;74:1401-1406. 
50. Grapes R. Pyrometamorphism, 2nd edn. Basel. Springer; 2010.

51. Feathers JF. Effects of temper on strength of ceramics: response to Bronksky and Hamer. Am Antiquity. 1989;54:375-579.

52. Holakooei P, Tessari U, Verde M, et al. A new look at XRD patterns of archaeological ceramic bodies an assessment for the firing temperature of 17 th century haft rang tiles from Iran. $J$ Therm Anal Calorim. 2014);118(1):165-176

53. Velraj G, Tamilarasu S, Ramya R. FTIR, XRD and SEM-EDS Studies of Archaeological Pottery Samples from Recently Excavated Site in Tamil Nadu, India. Mater Today Proc. 2015;2(3):934-942. 